http://dx.doi.org/10.12775/szhf.2014.050

KAROL MichalsKi

\title{
Formalne wskazanie jako zasada metodyczna w myśleniu hermeneutycznym Martina Heideggera
}

„Formalne wskazanie” (formale Anzeige) należy do centralnych pojęć myślenia filozoficznego Martina Heideggera. Formalne wskazanie jest pojęciem metodycznym. Od początków filozofii widziano istotny sens wskazywania, pokazywania (gr. deixis, łac. indicare) dla poznania i mowy. Mowa połączona jest $\mathrm{z}$ gestem wskazywania na rzeczy. Rozumienie świata i siebie samego przez człowieka osadzone jest na fundamencie deiktycznym. Formalne wskazanie występuje u Heideggera w konteście rozumienia wypowiedzi filozoficznej. Mowa formalnie wskazująca mówi nie wprost i daje wskazówkę.

W dziejach filozofii pojawiały się próby określenia mowy formalnie wskazującej. Karl Jaspers przejmuje od Kierkegaarda religijno-etyczne pojęcie „niebezpośredniego powiadamiania” (indirekte Mitteilung), nadając mu sens medium komunikacji egzystencjalnej ${ }^{1}$. Jaspers mówi o „prorokach niebezpośredniego powiadamiania”, do których zalicza Sokratesa, Kanta i Kierkegaar-

\footnotetext{
${ }^{1}$ K. Jaspers, Von der Wahrheit, R. Piper \& Co. Verlag, München-Zürich 1983, s. 648: „Niebezpośrednie powiadamianie jest mówieniem przez niemówienie, dokonuje się poprzez wieloznaczne działanie i przez wyjaśnianie otwartych symboli. Wprawdzie każde powiadamianie o prawdzie jest pewnym obiektywnie stającym się zjawiskiem, lecz sens i zrozumiałość tego zjawiska są istotnie różne według sposobu sensu prawdy".
} 
da, którzy - w odróżnieniu od „nauczycieli określonych zasad” i „nauczycieli totalności życia” - apelują do egzystencji człowieka².

W centrum myślenia Heideggera nad nowym rozumieniem filozofii, aż do końca lat dwudziestych, stoi pojęcie formalnego wskazania. Formalne wskazanie jest związane z przekształceniem myślenia fenomenologicznego w myślenie hermeneutyczne. Wczesne myślenie Heideggera określa się jako hermeneutykę formalnie wskazującą (formal anzeigende Hermeneutik) ${ }^{3}$. Wraz $\mathrm{z}$ formalnym wskazaniem dokonuje się istotny zwrot w sposobie rozumienia i wykładni hermeneutyki. Przestaje ona być metodycznym instrumentem interpretacji tekstów. Staje się metodą rozumienia i wyjaśnienia ludzkiego Dasein. W formalnym wskazaniu widzi Heidegger metodyczną zasadę pojęciowego ujęcia doświadczenia faktycznego życia.

Termin „formalne wskazanie” jako ugruntowanie filozoficznej pojęciowości wprowadził i rozwinął Heidegger zasadniczo we wczesnych Wykładach Fryburskich: Grundprobleme der Phänomenologie (1919/1920), Phänomenologie der Anschauungs und der Ausdrucks (1920), Einleitung in die Phänomenologie der Religion (1920/1921), Phänomenologische Interpretationen zu Aristoteles (1921/1922), Einführung in die Phänomenologische Forschung (1921/1922), Ontologie. Hermeneneutik der Faktizität (1923), w recenzji Anmerkungen zu Karl Jaspers „Psychologie der Weltanschauungen (1919/1921), w Wykładach Marburskich - Logik. Die Frage nach der Wahrheit (1925/1926) i Phänomenologie und Theologie (1927) oraz w Sein und Zeit (1927). Temat formalnego wskazania wystąpi jeszcze w późnym Wykładzie Fryburskim Die Grundbegriffe der Metaphysik (1929/30).

Jeżeli w późniejszych pismach Heidegger posługuje się już rzadko terminem „formalnie wskazujący” (formal anzeigend), to mówi ciągle jeszcze o „wskazaniu” (Anzeige) lub „wskazywaniu” (anzeigen). Terminem podobnym do "formalnego wskazania” jest używany przez Heideggera termin „skinienie” (Wink). Winken znaczy: dać znać. „Skinienie” jest zrozumiałe w kontekście tego, co Heidegger rozumie przez „zwrot” (Kehre) i „skok” (Sprung) w „inny początek” (Anfang) myślenia oraz w kontekście późniejszych tekstów o mowie.

Mowa formalnie wskazująca ma swoje źródło w gramatyce języka, w posługiwaniu się zaimkami osobowymi (np. ja, my itp.) i wskazującymi (np. ten,

${ }^{2}$ K. Jaspers, Psychologie der Weltanschauungen, R. Piper \& Co. Verlag, München 1985, s. 376-379.

${ }^{3}$ O. Pöggeler, Der Denkweg Martin Heideggers, Neske Verlag, Pfullingen 1963, s. 67-80. 
ta, to itp.) oraz okolicznikami miejsca (np. tu, tam itp.) i okolicznikami czasu (np. teraz, później, dziś, jutro itp.). W filozofii Heideggera, w pismach poprzedzających Sein und Zeit, występują pojęcia, które same w sobie są formalnymi wskazówkami, na przykład, „bycie-w świecie” (In-der-Welt-sein), „bycie-w” (in-sein) „ludzkie-bycie-tu” (Dasein), „eg-zystencja” (Ek-sistenz), „ja-teraz-tu” (ich-jetzt-hier). Póżniej Heidegger używa takich formalnych wskazówek, jak: „bliskość” (Nähe), „miejsce” (Ort), „okolica“ (Gegend), „krajobraz” (Landschaft) „stosunek” (Verhältnis), „przynależność” (Zugehörigkeit), „odniesienie” (Bezug).

Oprócz określenia „formalne wskazanie” Heidegger posługuje się także zwrotem "pojęcia formalnie wskazujące” (formal anzeigende Begriffe). Zwroty „formalne wskazanie” i „pojęcia formalnie wskazujące” są oryginalnymi tworami językowymi Heideggera, powstałymi w kontekście filozoficznym, w którym zrodziła się hermeneutyka faktyczności życia. W filozoficznym koncepcie formalnego wskazania wyraża Heidegger podstawowe przekonanie, że pojęcia hermeneutyczne nie przekazują wyczerpująco swojej zawartości, tylko formalnie wskazują. Hermeneutyczne pojęcia formalnego wskazania wyznaczają filozofii istotne zadanie nieustannego aktualizowania zawartości pojęciowej.

Problematyka formalnego wskazania stoi w centrum hermeneutycznego myślenia Heideggera. W Sein und Zeit formalne wskazanie pojawia się w różnych zastosowaniach, chociaż nie jest metodycznie wyjaśnione ${ }^{4}$. Formalne wskazanie stanowi metodyczny rdzeń filozofii Heideggera. Mimo to nie zostało ono w żadnym jego tekście systematycznie i wyczerpująco wyłożone ${ }^{5}$. Jedyna próba szczegółowego rozwinięcia problemu formalnego wskazania została podjęta we wczesnym Wykładzie Fryburskim z semestru zimowego 1920/21 i została zaraz na początku przerwana ${ }^{6}$.

${ }^{4}$ M. Heidegger, Sein und Zeit, Unverändeter Text mit Randbemerkungen des Autors aus dem „Hütenexemplar”, Hrsg. Fr.-W. von Herrmann, Gesamtausgabe, Band 2, Vittorio Klostermann, Frankfurt am Main 1977, ss. 14, 41, 43, 53, 114, 117, 231, 313, 315.

${ }^{5}$ W liście do K. Löwitha z 6 listopada 1924 informuje Heidegger, że pisze obszerny artykuł dla nowo powstałego czasopisma i ze względu na długość: „Musiałem to, co ważne pozostawić na boku, i tak, przede wszystkim, 'formalne wskazanie', które dla ostatecznego zrozumienia jest nieodzowne”. J. W. Storck und Th. Kisiel, Martin Heidegger und die Anfänge der Deutschen Vierteljahrsschrift für Literaturwissenschaft und Geistesgeschichte, „Dilthey Jahrbuch” 8 (1992/1993), s. 214.

${ }^{6}$ M. Heidegger, Einleitung in die Phänomenologie der Religion, [w:] Phänomenologie des religiösen Lebens, Hrsg. M. Jung, Th. Regehly, C. Strube, Gesamtausgabe, Bd. 60, Vittorio Klostermann, Frankfurt am Main 1995, s. 55. Heidegger miał zwyczaj podczas wykładów nietrzy- 


\section{Formalne wskazanie a metoda}

Jako termin ściśle metodyczny, formalne wskazanie zostało wprowadzone po raz pierwszy w krytycznej recenzji Heideggera do dzieła Jaspersa Psychologie der Weltanschauungen ${ }^{7}$ Heidegger dostrzega w rozprawie Jaspersa brak odpowiedniej metody dla rozważania problematyki egzystencji. Recenzja jest okazją do przedstawienia uwag na temat metody filozoficznej. Problem metody jest problemem filozoficznego ujmowania i wypowiadania. Metoda nie może być z góry wyznaczonym schematycznym modelem do zastosowania i do uzyskania wyników, jak klucz do otwierania drzwi. Metoda filozofii musi mieć to samo źródło, co przedmiot badania. Metoda kształtuje się właściwie wraz z tworzeniem treści pojęciowej. Dorasta się metodycznie do doświadczenia. Przystąpienie do badania filozoficznego jest problemem właściwej metody. Problematykę metodycznego początku nazywa Heidegger „problematyką antycypującą" (Vorgriffsproblematik). Zarówno faktyczne życie, które jest „przedmiotem” badania, jak i metoda badająca to życie, mają swoje ,antycypacje" (Vorgriffe), które muszą być wzięte pod uwagę, zanim przystąpi się do filozoficznego rozważania. „Problematyka antycypująca jest problematyką 'metody"'. Metoda musi liczyć się zarówno ze swoimi antycypacjami, jak i z uprzedniościami tego, co będzie badać, to znaczy, faktycznego życia. Metoda stojąca w obliczu życia nigdy nie jest gotową metodą, ale staje się nią dopiero. Życie zawsze wyprzedza metodę, dlatego musi zostać doświad-

mania się sztywno zapowiedzianego tematu. Zamiast realizować zapowiedziany na początku semestru temat, referował często swoje eksperymenty myślowe. Tak było też w przypadku wykładu, mającego wprowadzić w fenomenologię religii. Heidegger wchodzi od początku w tematykę formalnego wskazania. Studenci, słysząc rzeczy „niezwiązane” z tematem, zaprotestowali w dziekanacie z powodu braku religijnych treści. Heidegger przerywa wykładanie tematu formalnego wskazywania i rozpoczyna „Fenomenologiczne wyjaśnienie konkretnych religijnych fenomenów w nawiązaniu do listów Pawłowych". Nigdy nie wróci już do systematyczengo i wyczerpującego rozważania problemu formalnego wskazania.

${ }^{7}$ M. Heidegger, Anmerkungen zu Jaspers „Psychologie der Weltanschauungen”, [w:] M. Heidegger, Wegmarken, Text mit Randbemerkungen des Autors aus dem Handexemplar, Hrsg. Fr.-W. von Herrmann, Gesamtuasgabe, Bd. 9, Vittorio Klosteramann, Frankfurt am Main 2004, s. 1-45. Krytyczną recenzję, powstałą w latach 1919-1921, Heidegger wysłał w czerwcu 1921 do Jaspersa. Została opublikowana pierwotnie w: Karl Jaspers in der Diskussion, Hrsg. H. Saner, R. Piper \& Co. Verlag, München 1973, s. 70-100. W recenzji wyraża Heidegger podziw wobec podjętej przez Jaspersa problematyki egzystencji, zwłaszcza egzystencji w sytuacjach granicznych. Z drugiej zaś strony wytyka Jaspersowi ewidentne braki metodyczne.

8 Tamże, s. 9. 
czone w sposób antycypujący. Problem antycypacji życia i metody wiąże się u Heideggera $\mathrm{z}$ ideą filozofii jako pranauki (Urwissenschaft). Faktyczne doświadczenie życia (faktische Lebenserfahrung) ma być uchwycone w sposób poprzedzający teoretyczne rozważanie. Jest to zadanie „pranauki jako nauki przed-teoretycznej (vor-theoretische Wissenschaft)" . Metoda filozofii jako pranauki, ujmującej przedteoretycznie faktyczne doświadczenie życia, jest metodą w pierwotnym sensie: prametodą. Znaczenie metody (methodos, gr. „po drodze”), jakie nadała mu nowożytność jako uregulowanego postępowania (Verfahren) według wyznaczonego celu, wraca do swojego pierwotnego sensu drogi (odos) jako doświadczenia (Erfahren) poruszania się za formalnym wskazaniem. Pisze Heidegger:

Ustalenie sensu 'metody' powinno być w formalnie wskazującym znaczeniu (na przykład 'droga') otwarte na właściwe konkretne określenia. Jakkolwiek nie byłyby one pozyskane, to równocześnie z tym pozyskaniem, powinno się z kolei wtórnie anulować przesąd (Präjudiz), który być może wdarł się poprzez formalne wskazanie znaczenia ${ }^{10}$.

Metoda naukowa jest z góry nastawiona na określone izolowane zadania, określonej nauki rzeczowej, zmieniając i dopasowując technikę dostępu do przedmiotu i jego ujmowania. Metoda naukowa szuka potwierdzenia siebie w wynikach. Metoda filozoficzna, w przeciwieństwie do metody nauki, powinna rozwijać się wraz z doświadczaną rzeczą, towarzyszyć na drodze pokazywania się fenomenu faktycznego życia, pozostając w otwartości, na drodze formalnego wskazania. Otwartość metody formalnego wskazania niesie w sobie ryzyko przyjęcia niepożądanych treści, które trzeba ex post znaczeniowo unieważnić. Metoda formalnego wskazania w otwartości dopuszcza także to, co może być „nieprawdziwe”, aby następnie pozbawić to filozoficznej ważności.

Pisze Heidegger o „przedmiocie” metody formlnego wskazania:

To (co) przedmiotowe, zawarte w pytaniu, byłoby ustalone w formalnym wskazaniu jako egzystencja. W takim formalnie wskazującym znaczeniu, pojęcie ma wskazywać na fenomen 'ja jestem', na sens bycia, który leży w 'ja jestem’ jako

\footnotetext{
${ }_{9}^{9}$ M. Heidegger, Zur Bestimmung der Philosophie, Hrsg. B. Heimbüchel, Gesamtausgabe, Bd. 56/57, Vittorio Klostermann, Frankfurt am Main 1999, s. 95.

${ }^{10}$ M. Heidegger, Anmerkungen zu Karl Jaspers „Psychologie der Weltanschauungen“, Bd. 9, wyd. cyt., s. 9.
} 
zaczątek zasadniczego związku fenomenów i należącej do niego problematyki. Przez wskazanie formalne, (w którym należy widzieć metodyczny podstawowy sens wszelkich pojęć i związków pojęciowych, nie podlegający tutaj bliższej eksplikacji) ma się właśnie zapobiegać bezkrytycznemu popadnięciu w jakieś określone ujęcie egzystencji, choćby Kierkegaarda albo Nietzschego, po to, aby uzyskać możliwość pójścia tropem pierwotnego sensu fenomenu egzystencji i wyeksplikować drogę po tym tropie ${ }^{11}$.

Formalne wskazanie pozostawia treść pojęcia egzystencji w zawieszeniu i nieokreśleniu. Formalne wskazanie jest zasadą metodyczną, otwierającą drogę do określania pojęciowego. To, co formalnie wskazane, oznacza najpierw obszar, do którego coś należy. Obszarem, w którym porusza się i operuje formalne wskazanie jest obszar człowieka. To, co formalnie wskazane, nie musi być poddane teoretycznej oczywistości. Pojęcia formalnego wskazania nie muszą być teoretycznie wykazywalne. Człowiek jest formalnie wskazująco określony jako egzystencja. Egzystencja nie jest uchwycona w teoretycznych twierdzeniach, z których buduje się wiedzę ogólną. Nie można mówić o człowieku egzystującym faktycznie i dziejowo, wychodząc od pojęcia ogólnego. Heidegger pisze:

Aby w formalnym wskazaniu (określony stopień metodyczny eksplikacji fenomenologicznej, który nie będzie tutaj omawiany, który jednak, nawet w dalszym tekście, jest do pewnego stopnia zrozumiały) przygotować koncept problemu (dający się znowu, zgodnie ze swoim sensem, anulować), można powiedzieć tak: 'egzystencja' jest określonością czegoś; o ile chce się nią samą regionalnie scharakteryzować, chociaż ta charakteryzacja, ostatecznie i właściwie okazuje się mylącą dygresją wobec sensu egzystencji, to może ona być ujęta jako określony sposób bycia, jako określony sens- 'jest', który istotnie 'jest' sensem-(ja) 'jestem, który się źródłowo posiada nie w teoretycznym mniemaniu, lecz posiada się go w dokonaniu (Vollzug) 'jestem', jako sposób bycia 'ja.' Tak rozumiane bycie siebie oznacza, formalnie wskazująco, egzystencję ${ }^{12}$.

Wyjaśnienie daje wskazówkę, z czego musi być zaczerpnięty sens egzystencji. Decydujące jest podstawowe doświadczenie, że „posiadam” siebie samego, w którym napotykam siebie samego jako siebie. W tym samodoświadczeniu szukam odpowiedzi na pytanie o sens własnego sposobu bycia, wyrażonego w: ,ja jestem”. Formalnie wskazująco docieram do egzystencji, która jest moją

\footnotetext{
${ }^{11}$ Tamże, s. 10-11.

12 Tamże, s. 29.
} 
własną egzystencją. Egzystencja, którą usiłuję formalnie wskazująco ująć, jest moją aktualną egzystencją. Nie można powiedzieć, że Dasein jest pojęciem określającym bycie człowieka. Dasein jest tylko słowem wskazującym formalnie na bycie człowieka.

Pierwsze wyraźne rozwinięcie formalnego wskazania znajduje się w Heideggera wykładzie Einleitung in die Phänomenologie der Religion.

Metodyczne użycie sensu, które będzie wiodące dla eksplikacji fenomenologicznej, nazywamy 'formalnym wskazaniem'. Na fenomeny będzie się patrzeć pod kątem tego, co niesie $\mathrm{w}$ sobie sens formalnie wskazujący. $\mathrm{Z}$ rozważania metodycznego musi stać się zrozumiałe, dlaczego wskazanie formalne, chociaż jest ono wiodące dla rozważania (Betrachtung), to jednak nie wnosi w problemy jakiegoś uprzedniego twierdzenia. Trzeba sobie uświadomić sens formalnego wskazania, inaczej popadnie się albo w rozważanie nastawieniowe, albo w ograniczenia regionalne, które się traktuje potem jako absolutne ${ }^{13}$.

W wykładzie tym łączy Heidegger krytykę współczesnej filozofii religii (Troeltsch) z metodycznym rozważaniem dotyczącym odsłonięcia faktycznego doświadczenia życia w jego dziejowości. Na tym tle dokonuje fenomenologicznej analizy wczesnych świadectw pierwotnego chrześcijaństwa. $\mathrm{Na}$ fenomenie przepowiadania Pawłowego wyjaśnia podstawowe nastroje pierwotnej religijności chrześcijańskiej, w której rozpoznawalny jest żródłowy sposób wykonania (Vollzug) faktycznego życia. Problem metodycznego sensu formalnego wskazania jest dla Heideggera problemem ujęcia i wyartykułowania faktycznego doświadczenia życia. Formalne wskazanie fenomenu faktycznego życia prowadzi do problemu filozoficznego tworzenia pojęć. Jakie możemy mieć filozoficzne „pojęcie” o faktycznym życiu?

\section{Osobliwość pojęć formalnie wskazujących}

Filozoficzne pojęcia są dla Heideggera ze swojej natury „osobliwe” (eigentümlich). W poszczególnych naukach pojęcia zostają określone przez przyporządkowanie do rzeczy. Pojęcia naukowe stają się coraz dokładniej określone, w miarę postępu poznawania owej rzeczy.

Filozoficzne pojęcia, przeciwnie, są chwiejne, niejasne, wieloznaczne, płynne, jak się to pokazuje w zmianie filozoficznych punktów widzenia. Lecz ta nie-

${ }^{13}$ M. Heidegger, Einleitung in die Phänomenologie der Religion, dz. cyt., Bd. 60, s. 55. 
pewność filozoficznych pojęć nie jest wyłącznie ugruntowna w zmianie punktów widzenia; ona należy raczej do sensu filozoficznych pojęć, że one zawsze pozostają niepewne ${ }^{14}$.

Nauki zmierzają do pojęciowej pewności. Filozofia w ulotności pojęciowej widzi możliwość prawdziwego myślenia. Pojęcia formalnego wskazania są z istoty pojęciami niestabilnymi. Niepewność filozoficznych pojęć formalnie wskazujących nie wypływa z braku orientacji metodycznej. Nietrwałość formalnie wskazujących pojęć świadczy o istotnej zdolności filozofii do nieustannej korekty i nawrotu. Łatwiej zmienić coś nieutrwalonego niż coś zamrożonego, zastygłego, skostniałego.

Spojrzenie na historię filozofii pokazuje, że formalna określeniowość tego, co przedmiotowe, opanowuje całkowicie filozofię. Jak można uniknąć tej prejudycji, tego przesądu? Tego dokonuje właśnie formalne wskazanie ${ }^{15}$.

Tradycyjna filozofia koncentruje się jednostronnie na istocie fenomenu, na treści fenomenu, na przedmiocie. Tradycyjnemu filozofowaniu chodzi o teoretyczne określenie i opanowanie zawartości fenomenu. Formalne wskazanie natomiast usiłuje do tego określić jeszcze relację poznającego do poznawanego i poznawanego do poznającego, to znaczy sposób ujęcia fenomenu i oddziaływanie tego ujęcia. Dlatego pojęcia formalnie wskazujące "zawierają” sens treściowy (Gehaltssinn), sens relacyjny (Bezugssinn) i sens wykonaniowy $(\text { Vollzugssinn })^{16}$. Pojęcia formalnego wskazania nie są tylko ujęciem przedmiotowej treści i owocem podmiotowo-przedmiotowego schematu. Sens pojęć formalnie wskazujących jest dziełem całościowym ludzkiego Dasein. Sens całościowy (treściowy, relacyjny i wykonaniowy) wypełnia bytowanie całego Dasein.

Formalne wskazanie należy do fenomenologii. „Formalne wskazanie posiada sens tylko w odniesieniu do eksplikacji fenomenologicznej”"17. Spekulatywne i dialektyczne myślenie jest całkowicie obce zasadzie formalnego wskazania. Formalne wskazanie pozostaje w obrębie fenomenologii jako metody. Formalno-wskazujące rozjaśnianie jest częścią analityczno-opisowej metody fenomenologicznej. Formalne wskazanie nie ma nic wspólnego z co (Was) fe-

\footnotetext{
${ }^{14}$ Tamże, s. 3.

15 Tamże, s. 63.

16 Tamże.

17 Tamże.
} 
nomenologii jako filozofii transcendentalnej. Myślenie formalno-wskazujące jest jedynie urzeczywistnieniem jak (Wie) fenomenologii, jej metodycznej możliwości filozofowania ${ }^{18}$. Formalne wskazanie stanowi stopień metody fenomenologicznej, która w myśleniu Heideggera przybiera postać hermeneutyki fenomenologicznej. Fenomenologiczne widzenie uzupełnia Heidegger o hermeneutyczne rozumienie i wykładnię.

\section{Formalnie wskazujące definiowanie filozofii}

W wykładzie Phänomenologische Interpretationen zu Aristoteles koncentruje się Heidegger na idei filozofii, to znaczy, formalno-wskazującym definiowaniu filozofii. Pytanie o formalne wskazanie wypływa z pytania: Czym jest filozofia? Na czym polega zadanie filozofii? Przy określaniu idei filozoficznej definicji napotykamy sens tego, co zasadnicze, pryncypialne ${ }^{19}$. Zasada jest czymś, co wyjściowo decyduje o byciu czegoś, od czego wszystko zależy. Filozofia jest sposobem bycia, jest „poznającym zachowaniem” (erkennendes Verhalten). Filozoficzne poznanie mierzy w coś ostatecznego, ogólnego, najwyższego. Filozofia jest tym poznającym zachowaniem, które w sobie samym ma rację bycia, względem czegoś, czemu może służyć jako zasada. Określające ujęcie samej filozofii musi być pryncypialne. Filozofia jest zasadą swojego bycia i tego, co jest jej przedmiotem. Przedmiot, względem którego zachowuję się poznawczo, określa samo to zachowanie.

Z tego wynika zasadnicza formalnie wskazująca definicja filozofii: Filozofia jest zasadniczo poznającym zachowaniem względem bytu jako bycia (sens bycia), i to tak, że w zachowaniu i dla niego, chodzi również zdecydowanie o każdorazowe bycie (sens bycia) posiadania zachowania ${ }^{20}$.

\footnotetext{
${ }^{18}$ M. Heidegger, Sein und Zeit, Bd. 2, wyd. cyt., s. 37.

${ }^{19}$ Zarówno greckie słowo arche, jak i łacińskie słowo principium oznaczają w języku potocznym: początek i panowanie. Pod wpływem Arystotelesa „zasada” (arche) stała się jednym z najbardziej centralnych pojęć filozoficznych. Cała teoretyczna wiedza, według Arystotelesa, traktuje o przyczynach i zasadach. Filozofia, jako najwyższa wśród panujących nauk, jest teoretyczną nauką o pierwszych przyczynach i zasadach. W nowożytnej filozofii zasada znaczy „to, z czego coś pochodzi, lub zdarza się, lub zostaje poznane” (primum, unde aliquid est, aut fit, aut cognoscitur). W niemieckim idealizmie zasada jest używana w sensie "podstawowego twierdzenia" (Grundsatz), na przykład, dla budowy systemu.

${ }^{20}$ M. Heidegger, Phänomenologische Interpretationen zu Aristoteles. Einführung in die phänomenologische Forschung, Hrsg. W. Bröcker u. K. Bröcker-Oltmanns, Gesamtausgabe, Bd. 61, Vittorio Klostermann, Frankfurt am Main 1994, s. 60.
} 
Definiowanie w filozofii nie może być pedantycznym i ścisłym definiowaniem naukowym. Filozofia musi wypracować swój własny, zasadniczy i formalnie wskazujący, sposób budowania twierdzeń. Definiowanie filozofii nie jest tym, co ujmuje szkolna logika. Definicja filozofii jest filozofią definicji. Filozofia sensu bycia jest sensem bycia filozofii.

Filozoficzna definicja jest definicją zasadniczą, formalną i wskazującą. Filozoficzna definicja nie ma określonego przedmiotu, który określa jej sposób definiowania, tak jak: biologia, psychologia, socjologia. Każda nauka, według Heideggera, posiada swoją „sprawę” (Sache), każda nauka posiada swoje "mieć" (Haben). Nauka zakłada przedmiot postępowania badawczego. Filozofia nie ma swojej „sprawy”, swojego „mieć”. Filozofia jest pryncypialna. Pryncypialność filozofii nie polega na tym, że ustala zasady i kieruje się zasadami postępowania metodycznego. Pryncypium filozoficzne dotyczy sposobu (radykalny, ostateczny, gruntowny, formalny) poruszania się. Filozofia nie posiada określonego zmierzania do celu, „Tak więc musi ona być 'wskazującą' (anzeigend) (w tym): o co jej chodzi" ${ }^{21}$. To znaczy, że filozofia nie jest od razu skierowana na treść, na posiadanie treści. Wolna jest od troski zdobywania i posiadania rezultatów. Filozofia idzie za wskazaniem, nie wiedząc dokąd to wskazanie prowadzi. Wskazywać na coś jest czymś innym niż być przy czymś i pokazywać to. Wskazywać różni się od mieć coś na uwadze. Wskazuje się na kierunek, a nie na przedmiot, który się widzi. Wskazuję formalnie, nie stojąc na przeciw czegoś, nie widząc „przedmiotu” wskazania. Definiowanie filozoficzne jako wskazywanie jest kierowaniem spojrzenia nie w kierunku tego, co jest widzane, lecz w kierunku tego, co może być zobaczone. Nie pokazuję ani sobie czegoś, co widzę, ani nie pokazuję tego komuś, jak przewodnik w muzeum pokazuje zwiedzającym obrazy na ścianie. Wskazywanie wypływa z zasady filozoficznego definiowania. Chcąc filozoficznie definiować, mogę tylko kierować się wskazówką i iść konsekwentnie za wskazówką. We wskazywaniu nie jest nic zdecydowane. Heidegger nazywa wskazywanie "przed-'siębraniem”" (Vor-'kehrung') w odróżnieniu od określonego „obierania kierunku” (Kehre) na treść. Formalne wskazanie kryje w sobie coś przygotowawczego i zabezpieczającego.

W formalnym wskazaniu nie chodzi tylko o sposób poruszania się w kierunku konkretności, lecz także o obronę przed tym, co może zakłócić i zagrodzić drogę prowadzącą do widzenia i rozumienia. Formalne wskazanie nie jest tylko, w rozumieniu Heideggera, zasadą motywującą. „Formalne

${ }^{21}$ Tamże, s. 19. 
wskazanie ma w sobie samym, wraz ze wskazującym, równocześnie charakter prohibitywny (wzbraniający, odpierający)."22 Formalne wskazanie pełni jednocześnie funkcję prowadzenia i powstrzymywania. Prohibitywny charakter formalnego wskazania wyraża sens, aby wszystkie nieodpowiednie kategorialne (zamiast egzystencjalne) analizy trzymać z daleka. Formalne wskazanie pozostaje $\mathrm{w}$ związku z destrukcją fenomenologiczną, a to oznacza, że w hermeneutyce fenomenologicznej Heideggera łączy się z zabiegiem oczyszczania pojęciowego. Formalne wskazywanie stawia opór nieugruntowanemu tworzeniu pojęć, sztucznemu konstruowaniu, uprzedzonemu stwierdzaniu i orzekaniu. W formalnym wskazaniu zakorzeniona jest hermeneutyczna troska o właściwe budowanie i interpretowanie filozoficznych pojęć.

Wskazywanie definiowania filozoficznego nie jest takim wskazywaniem, w którym wskazujący podmiot stoi naprzeciw wskazywanego przedmiotu (Gegenstand). Wskazywanie nie jest wskazywaniem tego, co się już od początku mgliście i w zarysach widzi, a co będzie jawiło się coraz bardziej konkretnie. Definicja filozoficzna w tym sensie nie ma materialnego nastawienia. "Jest ona 'formalnie' wskazującą, 'drogą, w przystąpieniu (Ansatz)"23. Co to znaczy, że wskazywanie jest formalnym wskazywaniem? Co oznacza „formalny”? Słowo „formalny” nie występuje tutaj w znaczeniu logiki tradycyjnej, jako przeciwieństwo słowa „materialny”. „Formalny” nie jest elementem konstrukcji „forma-materia”. Formalny jest, w pewnym sensie, jednocześnie materialny. Formalne wypełnia się źródłowo we wskazywaniu. Formalne we wskazywaniu materializuje się $\mathrm{w}$ pokazywaniu kierunku. Istotnym sensem tego, co formalne, jest wskazywanie.

'Wskazany formalnie' nie oznacza jakoś tylko przedstawiony, pomyślany, zasugerowany, tak, że stałby teraz wolno, nie (oznacza) uchwycić sam przedmiot gdzieś i jakoś, lecz wskazany tak, że to, co jest powiedziane, jest z charakteru tego 'formalnego' niewłaściwe, ale właśnie w tym 'nie'-(jest) jednocześnie pozytywna instrukcja. To, co pusto treściowe w jego strukturze sensu jest jednocześnie tym, co nadaje kierunek ${ }^{24}$.

Drogowskaz nie pokazuje celu, lecz kierunek do celu. Nazwa „formalny” nie oznacza, że chodzi tutaj o coś niezobowiązującego i niewiążącego. Nawet jeżeli chodzi w formalnym wskazaniu o treściową nieokreśloność, to jest to

\footnotetext{
${ }^{22}$ Tamże, s. 141.

${ }^{23}$ Tamże, s. 20.

${ }^{24}$ Tamże, s. 33.
} 
coś decydującego dla hermeneutycznego widzenia i rozumienia. Formalne wskazanie jest nastawione na „pusty przedmiot”, „pustą treść”. W formalnym wskazaniu nie ma dowolności i przypadkowości. W formalnym wskazaniu rozchodzi się o ,istotną pustkę", niczym nie uwarunkowane i beztroskie (unbekümmert) wskazywanie kierunku.

\section{Istotny sens formalnego wskazania}

\section{Pisze Heidegger o istotnym sensie formalnego wskazania:}

W formalnym wskazaniu leży pewna określona więź (Bindung); jest w niej powiedziane, że stoję przy pewnym określonym kierunku przystąienia (Ansatzrichtung), że, jeżeli miałoby przyjść do czegoś właściwego, to jest tylko ta droga, by to, co niewłaściwie wskazane, wykosztować i wypełnić, by iść za wskazówką. Wykosztowanie (Auskosten), wyciągnięcie z niego: właśnie takie, że im bardziej ono przystępuje, to nie tym mniej (pomniejszająco) zyskuje, tylko odwrotnie, im radykalniejsze rozumienie pustego, jako w ten sposób formalnego, tym jest bogaciej, ponieważ jest tak, że prowadzi to do konkretu ${ }^{25}$.

W formalnym wskazaniu trzeba przede wszystkim wytworzyć pozytywną relację do drogi. Trzeba zdecydować się na określoną drogę, nawet jeżeli miałaby się okazać błędną drogą. Poruszać się formalnie wskazująco na drodze znaczy: smakować przebieg drogi, rozkoszować się pokonywaniem drogi. Chodzi o intensywne rozsmakowanie się drogą. Dopiero wykosztowanie, wysmakowanie drogi może zostać nagrodzone zobaczeniem i rozumieniem konkretu. Kiedy wyruszam w drogę za wskazaniem formalnym, to nie mogę od początku zwracać uwagi na konkretny cel. Podążanie formalno-wskazujące jest całkowitym koncentrowaniem się na drodze, jakby nie było celu ${ }^{26}$.

\footnotetext{
${ }^{25}$ Tamże.

${ }^{26}$ Droga ma prowadzić do celu. Podróżnicy, określani mianem ekstremalnych wędrowców (Grenzgänger), posługują się ostatnio zapożyczonym z buddyzmu wyrażeniem: „droga jest celem”. Ponieważ większość celów została osiągnięta, dlatego usiłuje się szukać nowych dróg do tych samych celów. Ekstremalny wędrowiec i alpinista z południowego Tyrolu R. Messner posuwa się jeszcze dalej, kiedy mówi, „To nie sam szczyt, ani też nie droga, ale droga okrężna jest celem”, R. Messner, Bis ans Ende der Welt, Alpine Herausforderungen im Himalaya und Karakorum, BLV Verlagsgesellschaft, München-Wien-Zürich 1994, s. 7. Pod słowem „droga okrężna" pierwszy zdobywca wszystkich czternastu ośmiotysięczników rozumie nie tylko drogę, która na przykład prowadziłaby spiralnie wokół szczytu. Droga okrężna to także droga pokonywana samotnie, bez maski tlenowej, przebyta w czasie monsunu lub zimą.
} 
W podążaniu za formalnym wskazaniem droga jest w pewnym sensie od początku celem samym w sobie. Czymś istotnym jest tutaj podkreślane ciągle przez Heideggera słowo „przystąpienie”, „przyłożenie” (Ansatz). W tym słowie kryje się sposób rozumienia sensu początku drogi. Istotny jest moment obrania drogi, wstąpienia na drogę i udania się w drogę.

Wskazanie trzyma się zawsze $\mathrm{w}$ dystansie pokazywania. To znaczy, że ten komu pokazuje się, sam musi to wypatrzeć i zobaczyć. To, co w pokazywaniu pokazane, musi on sam widzieć, rozumieć, ująć w słowa i wypowiedzieć. Formalne wskazanie podaje tylko kierunek, w którym się patrzy. Trzeba uczyć się samemu widzieć, rozumieć i wypowiadać własnymi słowami to, co się pokazuje. Wypełnienie tego, co się pokazuje, musi być własnym dokonaniem (Vollzug) każdego filozofującego.

Definicja filozoficzna, jako zasadniczo formalnie wskazująca, nie wyraża jakiegoś formalizmu filozoficznego. Formalne wskazanie nie jest czystym delektowaniem się formą. Forma nie jest celem hermeneutyki Heideggera. To, co formalnie puste, musi zostać zdeformalizowane. Ostatecznym celem formalnego wskazania jest widzenie i rozumienie konkretu. Heidegger mówi o konkretności (Konkretion) w odróżnieniu od konkretyzacji. „Treść definiująca 'wskazuje' źródłową, jako konieczną do wskazania, konkretność." ${ }^{27}$ Definicja formalnie wskazująca nie zawiera uogólnionej konkretności. Definicja wskazuje formalnie na konkretność. Definicja jako formalnie wskazująca nie oddaje w pełni przedmiotu określanego, tylko wskazuje na źródło konkretności. Taki jest sens wskazania, że pozostawia drogę do konkretności zawsze otwartą. Tą źródłową konkretnością jest dla Heideggera „ruchliwość faktycznego życia" (Bewegtheit des faktischen Lebens), która wyprzedza każde usiłowanie widzenia i rozumienia. Dlatego metoda, mająca za "przedmiot” życie, może tylko formalnie wskazywać.

Postępowanie według zasady formalnego wskazania jest w wykładni Heideggera postępowaniem według fenomenologicznej maksymy „powrotu do rzeczy”. Metoda formalnego wskazania odpowiada myśleniu z rzeczy samych. Pisze Heidegger w wykładzie Ontologie (Hermeneutik der Faktizität):

Formalne wskazanie jest niewłaściwie rozumiane zawsze wtedy, gdy bierze się je jako zwarte twierdzenie ogólne i z niego się konstruktywnie dialektycznie dedukuje i fantazjuje. Wszystko zależy od tego, żeby z nieokreślonej, ale jakoś zrozumiałej treści wskazania skierować rozumienie na właściwy tor widzenia

\footnotetext{
${ }^{27}$ M. Heidegger, Phänomenologische Interpretationen zu Aristoteles, Bd. 61, wyd. cyt., s. 31.
} 
(Blickbahn). Pozyskanie tego toru patrzenia może i musi być zapobiegawczo wsparte przez odrzucenie pozornie pokrewnych i dlatego samonarzucających się pozycji widzenia, jakie to panują w każdorazowej sytuacji badawczej ${ }^{28}$.

Początkowa zrozumiałość treści formalnego wskazania wypełnia się w spojrzeniu na konkretne źródło. Formalno-wskazująca tendencja jest wyrazem dokonaniowego (vollzugsmäßig) sposobu zachowania poznawczego $\mathrm{w}$ przeciwieństwie do konstrukcyjnych i schematycznych systemów teoriopoznawczych. Co to znaczy: „skierować rozumienie na właściwy tor widzenia (Blickbahn)"? W słynnym tekście Phänomenologische Interpretationen zu Aristoteles (Anzeige der hermeneutischen Situation), nazywanym krótko $\mathrm{Na-}$ torp-Bericht, z 1922 roku, wskazuje Heidegger na trzy warunki wykładni hermeneutycznej według pola rzeczowego (Sachfeld) i poznawczego roszczenia (Erkentnnisanspruch): Blickstand (punkt widzenia), Blickhabe (posiadanie spojrzenia) i Blickbahn (tor widzenia) ${ }^{29}$. Punkt widzenia obejmuje to, z czego zostaje dokonana interpretacja, czyli każdorazowy sposób bycia Dasein w sytuacji życia - sytuację egzystencjalną. Posiadanie spojrzenia (mieć coś na oku) dotyczy wstępnego określenia rzeczowej zawartości tego, co tema-

${ }^{28}$ M. Heidegger, Ontologie (Hermeneutik der Faktizität), Hrsg. K. Bröcker-Oltmanns, Gesamtausgabe, Bd. 63, Vittorio Klostermann, Frankfurt am Main 1995, s. 80.

${ }^{29}$ M. Heidegger, Phänomenologische Interpretationen zu Aristoteles (Anzeige der hermeneutischen Situation). Ausarbeitung für die Marburger und Göttinger Philosophische Fakultät (Herbst 1922), Text des Tiposkripts mit den handschriftlichen Zusätzen und Randbemerkungen des Autors aus seinem Exemplar, w: Phänomenologische Interpretationen ausgewählter Abhandlungen des Aristoteles zur Ontologie und Logik, Hrsg. G. Neumann, Gesamtausgabe, Bd. 62, Vittorio Klostermann, Frankfurt am Main 2005, s. 345.

Tekst powstał w roku $1922 \mathrm{w}$ związku z planowanym ponownym obsadzeniem dwóch filozoficznych katedr: w Marburgu i Göttingen. Heidegger był brany pod uwagę jako odpowiedni kandydat do objęcia katedry w Marburgu jako następca Nicolaia Hartmanna, który zajmował katedrę tymczasowo po przejściu na emeryturę Paula Natorpa oraz na katedrę w Göttingen po Edmundzie Husserlu, zajmowaną od 1919 przez ucznia Diltheya, Hermana Nohla, który objął w 1922 katedrę filozofii i pedagogiki. O powołanie Heideggera na te wolne katedry zwrócili się równocześnie Paul Natorp i Georg Misch do swojego kolegi z Fryburga Bryzgowijskiego Edmunda Husserla. Wystąpili do niego z prośbą o sprawozdanie z działalności nauczycielskiej i publikacyjnych planów Heideggera. Natorp życzył sobie, aby asystent Husserla przysłał mu jakiś gotowy do druku manuskrypt Heideggera. W Natorp Bericht Heidegger zdaje sprawę z kierunku i stanu swoich badań nad Arystotelesem, które miały się ukazać drukiem w 1924 roku pod tytułem Phänomenologische Interpretationen zu Aristoteles w VII i VIII tomie wydawanego przez Husserla "Jahrbuch für Philosophie und phänomenologische Forschung”. Pod koniec roku 1924 zrezygnował jednak z opublikowania zaplanowej książki o Arystotelesie. 
tycznie jest podjęte przez wykładnię. Tor widzenia wyznacza kierunek pytania intepretacyjnego. Dalej formułuje Heidegger nieco inaczej trzy warunki wykładni według pola rzeczowego i poznawczego roszczenia jako: Blickstand (punkt widzenia), Blickrichtung (kierunek widzenia) i Sichtweite (zasięg widzenia $)^{30}$. Wykładnia uwarunkowana jest różnymi sposobami bycia widzenia. To nie jest fenomenologiczne widzenie oglądu kategorialnego. Widzenie występuje ściśle $\mathrm{z}$ rozumieniem. Warunkiem prawdziwej wykładni jest hermeneutyczne widzące rozumienie. Prawdziwość i skuteczność wykładni leży w sile rozumiejącego widzenia.

\section{Formalno-wskazujące nastawienie filozofii do teologii}

Ponownie podejmuje Heidegger problem formalnie wskazującej definicji w wykładzie Phänomenologie und Theologie. W wykładzie tym ignoruje - prowadzące do napięć i walki - popularne ujęcie relacji teologii do filozofii, opierające się na przeciwieństwach wiary i nauki, objawienia i rozumu. Problem relacji teologii i filozofii ujmuje od początku inaczej - jako pytanie o relację dwóch nauk. W zakończeniu wykładu zastanawia się nad statusem filozofii wobec podstawowych pojęć teologii jako nauki. W zasięgu filozofii nie leży ugruntowanie pojęć teologicznych, których treść pochodzi $\mathrm{z}$ doświadczenia wiary. Niemniej jednak pojęcia teologii mogą stać się przedmiotem refleksji filozoficznej. Filozofia może na swój sposób uzasadniać pojęcia teologiczne. Filozofia nie może wystąpić wobec teologii w charakterze „wytycznej” (Direktion), mającej za zadanie prowadzenie myślenia. Filozofia może spełniać swoje zadanie dla teologii jedynie w charakterze „korekty” (Korrektion) w formalnym wskazaniu. W takim stopniu, w jakim filozofia formalnie wskazuje pojęcia egzystencjalne, może być pomocna dla teologii. Dla wyjaśnienia tego zagadnienia Heidegger wybrał nieprzypadkowo teologiczne pojęcie „grzechu”, egzystencjalnie współwystępujące z filozoficznym pojęciem „winy”. Filozoficzne rozjaśnienie pojęcia „winy” może pomóc korekcyjnie, formalnie wskazująco, w uzasadnieniu i wyjaśnieniu pojęcia "grzechu”, ponieważ pojęcia teologiczne mają charakter egzystencjalny. „Wszystkie teologiczne pojęcia kryją w sobie w sposób konieczny to rozumienie bycia, które ludzkie Dasein jako takie posiada z siebie samego, o ile w ogóle egzystuje." ${ }^{31}$ Pojęcia teologiczne zawierają w sobie, według Heideggera, pewne

\footnotetext{
30 Tamże, s. 346.

${ }^{31}$ M. Heidegger, Phänomenologie und Theologie, [w:] Wegmarken, Bd. 9, wyd. cyt., s. 63.
} 
specyficzne „przejście egzystencjalne” (existenzieller Übergang), w którym egzystencja przedchrześcijańska i chrześcijańska jednoczą się na swój sposób. Dzięki temu przejściu pojęcia teologiczne mogą być zbudowane na pojęciach egzystencjalnych (gratia supponit naturam). Funkcja korekcyjna filozofii względem teologii rozciąga się tylko na te pojęcia, które należą zarówno do filozofii, jak i do teologii. Pisze Heidegger:

Filozofia jest możliwą formalnie wskazującą ontologiczną korektą ontycznej, a mianowicie, przedchrześcijańskiej zawartości podstawowych pojęć teologicznych. Ale filozofia może także być tym, czym jest, bez tego korekcyjnego funkcjonowania ${ }^{32}$.

To kategoryczne stwierdzenie podkreśla suwerenność filozofii i wypowiada jej absolutny rozdział od teologii. Ten rozdział przypomina radykalne rozdzielenie filozofii od światopoglądu w fenomenologii Husserla. W relacji do teologii filozofia jest tylko możliwą korektą. Filozofia potrafi jednak wypełnić swoje istotne przeznaczenie bez pomocniczej funkcji wobec teologii. Filozofia może pomóc teologii, ale sama do niczego jej nie potrzebuje. Filozofia nie może wypowiadać się o teologicznych pojęciach, zawierających prawdy wiary. Może tylko filozoficznie interpretować pojęcia teologiczne $\mathrm{w}$ ich przedchrześcijańskiej zawartości, to znaczy w ich neutralnym znaczeniu. Ta pozytywna, możliwa relacja filozofii do teologii zawiera radykalną i gwałtowaną myśl, że „wiara w jej najbardziej wewnętrznym rdzeniu [...] pozostaje wobec filozofi śmiertelnym wrogiem"33.

\section{Formalne wskazanie egzystencji}

Pojęcia formalnego wskazania nie są $\mathrm{w}$ hermeneutyce Heideggera pojęciami w rozumieniu tradycyjnym, jako proste formy znaczeniowe. Rozumienie pojęcia formalnego wskazania jest bliskie rozumieniu idei Kanta w Kritik der reinen Vernunft, w taki sposób, jak je sobie Heidegger przyswaja i interpretu$\mathrm{je}^{34}$. Pojęcie ,idei” zawiera w sobie pewien negatywny moment. Idea ze swojej istoty nie oddaje czegoś. Idea nie oddaje przedmiotu w pełnej adekwatności, nie oddaje w swojej zamkniętej określoności istotnych elementów przedmiotu. W idei muszą być określone i oddane inne charakterystyczne elementy

\footnotetext{
32 Tamże, s. 66.

${ }^{33}$ Tamże.

${ }^{34}$ M. Heidegger, Zur Bestimmung der Philosophie, Bd. 56/57, wyd. cyt., s. 13-15.
} 
przedmiotu. Idea nie oddaje swojego przedmiotu w pełni i ciągle pozostaje otwarta na możliwość treściowego uzupełnienia. Pisze Heidegger w wykładzie Zur Bestimmung der Philosophie z 1919:

Idea nie oddaje wprawdzie ostatecznej, nie przekraczalnej już określoności jej przedmiotu, ale oznacza ona i dokonuje istotnie o wiele więcej niż wszelkie rozmyte przedstawienie i przypuszczenie. Możliwość wystąpienia (Heraustreten) i przyłączenia-się (Sich-Ansetzen) nowych istotnych elementów nie jest pustą możliwością formalno-logiczną, czyli treściowo samowolną, przypadkową. Możliwość ta jest określona, według prawa istoty ponowiona. Wprawdzie nie jej przedmiot, lecz ona sama jest ostatecznie określalna, ona sama nie pozostawia w swym sensie nic otwartego, ona jest pewną ostatecznie określalną określonością. Ta dająca się spełnić i w pozyskanej idei spełniona określoność, umożliwia to, aby konieczną i w określoności nie spełnialną nieokreśloność idei przedmiotu, przeprowadzić w nieokreśloną określoność. (Określalna określoność idei - określona nieokreśloność idei przedmiotu ${ }^{35}$.

Mówi się, że „mam jakąś ideę”, to znaczy, posiadam mgliste pojęcie o czymś, które może się krystalizować. Idea w sensie filozoficznym nie jest rozmytym przedstawieniem znaczenia, które może stawać się coraz bardziej wyraźne. Idea filozoficzna zawiera w sobie już istotne elementy treściowe jako ostatecznie określone. Ma w sobie jednak określoną możliwość pozyskiwania ciągle nowych istotnych elementów treściowych. Idea nie jest tym samym ani zamkniętą hermetycznie formą, obejmującą treść, ani też nieszczelną formą, do której wnętrza wnikają w sposób przypadkowy nieistotne treści. Idea filozoficzna jako forma myślenia posiada określoną możliwość otwierania się na przyjmowanie treści. Idea $\mathrm{z}$ istoty swojej reguluje przepływ i przechodzenie treści.

Metodyczna zasada formalnego wskazania trzyma się z dala od poznawczego schematu dzielącego rzeczywistość na podmioty i przedmioty.

To konstrukcyjne, przez upartość zatwardziałej tradycji, prawie nie do wytrzebienia przedsięwzięcie, zabudowało zasadniczo i na zawsze dostęp do tego, co jako faktyczne życie (Dasein) jest wskazywane (angezeigt) ${ }^{36}$.

\footnotetext{
${ }^{35}$ Tamże, s. 14.

${ }^{36}$ M. Heidegger, Ontologie (Hermeneutik der Faktizität), Bd. 63, wyd. cyt., s. 81.
} 
Myślenie w schemacie podmiot-przedmiot sprzeciwia się myśleniu według zasady formalnego wskazania, otwierającemu dostęp do egzystencji i tworzącemu pojęcia formalnie wskazujące. Żadna też modyfikacja schematu: podmiot-przedmiot nie sprosta wymaganiu doświadczenia faktycznego i dziejowego życia.

W Sein und Zeit, tak jak w recenzji do dzieła Jaspersa Psychologie der Weltanschauungen, formalne wskazanie zostało rozwinięte $\mathrm{w}$ związku z pojęciem Dasein, egzystencji.

Analiza tego bycia (Dasein) obrała sobie za nić przewodnią to, co zostało antycypująco (vorgreifend) określone jako istota Dasein, egzystencję. Ten tytuł oznacza w formalnym wskazaniu: Dasein jest rozumiejącą możliwością bycia (Seinkönnen), któremu w tym byciu chodzi o bycie jako własne bycie. Bytem, w ten sposób bytującym, jestem ja sam ${ }^{37}$.

Formalne wskazanie idei egzystencji było wyprowadzone od tego, tkwiącego w samym Dasein, rozumienia bycia. [...] Tym bytującym, które nazywamy Dasein, jestem ja sam, a mianowicie, jako możliwość bycia (Seinkönnen), któremu chodzi o to, aby być tym bytującym ${ }^{38}$.

Dasein rozumie bycie samo, bycie w ogóle, ponieważ rozumie i wyjaśnia sobie samemu bycie jako własne bycie. Heidegger wprowadza tutaj niezwykle ważną strukturę hermeneutyczną Jako $(\mathrm{Als})$. Formalne wskazanie łączy się istotnie ze strukturą Jako, która stanowi podstawę budowania pojęć filozoficznych.

\section{Formalne wskazanie a struktura Jako}

Hermeneutyczną strukturę Jako tematyzuje i rozwija Heidegger w wykładzie Logik. Die Frage nach der Wahrheit i w wykładzie Die Grundbegriffe der Metaphysik. Heidegger wyróżnia Jako apofantyczne i Jako hermeneutyczne. Jako apofantyczne dotyczy wypowiedzi ${ }^{39}$. Hermeneutyczne Jako dotyczy rozumiejącego i wyjaśniającego sposobu obchodzenia się z otaczającym nas

\footnotetext{
${ }^{37}$ M. Heidegger, Sein und Zeit, Bd. 2, wyd. cyt., s. 307.

${ }^{38}$ Tamże, s. 415.

${ }^{39}$ Apophansis nazywa Arystoteles twór językowy, który może oznaczać wypowiadanie prawdy albo fałszu. Apophansis może, według Arystotelesa, wystąpić jako kataphasis (potwierdzenie) lub apophasis (zaprzeczenie). Apofantyczny oznacza językowe wyrażenie określające wypowiadanie (prawdy lub fałszu) w odróżnieniu na przykład od pytania lub proszenia.
} 
światem rzeczy. Jako jest hermeneutycznym sposobem ujmowania i wypowiadania. „Nasze zorientowane bycie ku rzeczom i ludziom porusza się w tej strukturze tego: coś jako coś-krótko: posiada Jako-strukturę"40. U podłoża rozumienia i wyjaśnienia struktury Jako leży, według Heideggera, podwójna relacja do świata: relacja podręczności (Vorhandenheit) i relacja poręczności (Zuhandenheit) ${ }^{41}$. W relacji podręczności świat jest odbierany tak, jak jest zastany: byt objawia się jako byt. W relacji poręczności natomiast wykonany jest intencjonalny ruch w kierunku świata. Rzecz świata w relacji poręczności przemienia się, według Heideggera, w rzecz-narzędzie (Zeug). Na przykład napotkane pióro jest czymś podręcznym (vorhanden), to znaczy, zrozumiane $\mathrm{w}$ jego podstawowym znaczeniu, ale bez określonego przeznaczenia. Pióro może być zrozumiane jako rzecz poręczna (zuhanden), to znaczy, dostępna w tym, do czego służy, w tym, jak będzie używane. Tę służebność odsłania struktura Jako. Dzięki hermeneutycznej strukturze Jako napotkane podręcznie pióro może służyć jako poręczne narzędzie do pisania. Jako dotyczy określania, to znaczy osłaniania sensu rzeczy. Poręczność nie musi się odnosić tylko do rzeczy, mających dla nas już jakieś znaczenie, jak stól, przy którym się siada. Relacja poręczności może dotyczyć pierwotnej sytuacji człowieka, który ma do czynienia z surowym materiałem rudy żelaza, drewna, kamienia, gliny. Pierwsze odkrycia i wynalazki ludzkości, jak ogień czy koło, które określiły bieg cywilizacji, są wyrazem wejścia w relację poręczności. „To 'jako' ma funkcję odkrywania czegoś-z-czegos'”" . Jako charakteryzuje się możliwością wydobywania. Chodzi o wydobywanie na jaw tego, co ta rzecz już w sobie posiada, jak powiada Heidegger, jej „Haben”. Jako wyprowadza na jaw to, co ta rzecz potencjalnie już w sobie ma.

Czym jest Jako jako pojęcie? Czy potrafimy ująć istotny sens struktury Jako?

Musimy tylko wziąć pod uwagę, że formalna charakterystyka nie oddaje isto$t y$, lecz odwrotnie, najwyżej pokazuje właśnie tylko to decydujące zadanie, aby pojąć relację z jej własnego wymiaru, zamiast odwrotnie, zniwelować wymiar przez formalną charakterystykę. Oznaczenie 'jako' w sensie relacji, nie orzeka nic o 'jako’ jako takim, lecz zawiera jedynie wskazówkę do osobliwego zadania.

\footnotetext{
${ }^{40}$ M. Heidegger, Logik. Die Frage nach der Wahrheit, Hrsg. W. Biemel, Gesamtausgabe, Bd. 21, Vittorio Klostermann, Frankfurt am Main 1995, s. 144.

${ }^{41}$ M. Heidegger, Sein und Zeit, Bd. 2, wyd. cyt., s. 136-139.

${ }^{42}$ M. Heidegger, Logik. Die Frage nach der Wahrheit, Bd. 21, wyd. cyt., s. 150.
} 
Stąd mówię, ze względu na taką charakterystykę 'jako', o formalnym wskaza$n i u^{43}$.

Struktura Jako jest formalną strukturą. Tworzy formalną relację do napotkanego fenomenu. Formalnym zadaniem Jako jest przerzucić most na drugą stronę brzegu. Jako umożliwia jedynie dostęp, ponieważ jest tylko czymś formalnie wskazującym. Samego sensu Jako nie potrafimy scharakteryzować i pojąć w jego istocie. Możemy jedynie zrozumieć Jako formalnie wskazująco. Możemy tylko zrozumieć Jako w jego funkcji określania. To ma niezwykle ważne znaczenie dla całego filozoficznego pojęciowego wyrażania się, które może być tylko formalnie wskazującym. Istnieją pojęcia, o których w ogóle nie moglibyśmy się wypowiadać, gdyby nie było możliwości formalno-wskazującej wykładni. Heidegger stwierdza stanowczo: „Wszystkie pojęcia filozoficzne są formalnie wskazujące, i tylko, jeżeli będą tak ujęte, to dają prawdziwą możliwość pojmowania" ${ }^{34}$. Co to znaczy, że wszystkie pojęcia filozofii są formalnie wskazujące? Zasadniczo mamy widząco-rozumiejąco dostęp do rzeczy poprzez formalne wskazanie. Rzeczy dają się pojąć w pojęciach formalnie wskazujących. Ale samo formalne wskazanie jest też pojęciem, tak samo, jak hermenutyczna struktura Jako. Jak mamy rozumieć pojęcia „formalne wskazanie" i „strukturalne Jako"? Nie potrafimy dotrzeć do istotnego znaczenia tych pojęć. Sens tych pojęć jawi nam się w ich własnym wymiarze. Sens tych pojęć jest nam dostępny w ich formalnej i strukturalnej funkcji.

\section{Sens hermeneutyczny formalnego wskazania}

Filozoficzne pojęcia, jako formalno-wskazujące, różnią się gruntownie od pojęć naukowych. Na przykładzie śmierci pokazuje Heidegger osobliwy charakter pojęcia formalnie wskazującego ${ }^{45}$. Dasein człowieka jest byciem ku śmierci. Człowiek egzystuje na przeciw śmierci. Egzystować ku śmierci nie znaczy: żyć świadomością śmierci, ciągle myśleć o śmierci. Dasein jako możliwość bycia może zachować się (sich verhalten) wobec możliwości śmierci. Aby to osiągnąć, musi mieć pojęcie o śmierci. Pojęcie śmierci może być tylko pojęciem formalnie wskazującym. To znaczy może wskazywać na moją własną śmierć. Mogę mieć tylko pojęcie o własnej śmierci. Interpreta-

\footnotetext{
${ }^{43}$ M. Heidegger, Die Grundbegriffe der Metaphysik, Hrsg. Fr.-W. von Herrmann, Gesamtuasgabe, Bd. 29/30, Vittorio Klostermann, Frakfurt am Main 2004, s. 425.

${ }^{44}$ Tamże.

${ }^{45}$ Tamże, s. 425-427. Także M. Heidegger, Sein und Zeit, s. 316-345.
} 
cja (rozumienie i wykładnia) pojęcia własnej śmierci dotyka bycia Dasein. Formalnie wskazujące „pojęcia są wtedy tylko zrozumiałe, jeżeli nie będą ujęte jako znaczenia dotyczące właściwości i uposażeń tego, co jest podręczne (eines Vorhandenen), lecz jako wskazania na to, że rozumienie musi najpierw wymknąć się z potocznych ujęć bytującego i musi się jedynie przemienić w Da-sein" " Dla Heideggera w każdym pojęciu formalnie wskazującym, na przykład, „śmierć”, „zdecydowanie”, „dzieje”, „egzystencja”, leży wezwanie do przemiany. To wezwanie nie jest apelem moralnym. A przemiana nie jest rozumiana jako praktyczne zastosowanie etyczne. Wezwanie i przemiana mają sens egzystencjalny. Przemiana egzystencjalna należy, tak jak rozumienie i wyjaśnienie, do przebiegu hermeneutycznego pojmowania. Zamyka hermeneutyczne wydarzenie. To trojakie pojęcie hermeneutyki jest zapożyczeniem $\mathrm{z}$ hermeneutyki biblijnej protestanckiego ruchu pietystycznego ${ }^{47}$. Formalnie wskazujące pojęcia są ostatecznie zrozumiałe w przemianie ludzkiego Dasein. W możliwości do przemiany tkwi znaczeniowa siła tych pojęć. Formalnie wskazujące pojęcia trzeba samemu zrealizować.

Ponieważ pojęcia te, o ile są prawdziwie pozyskane, pozwalają zawsze tylko wypowiedzieć roszczenie takiej przemiany, lecz nigdy same tej przemiany nie potrafią wywołać, dlatego są one wskazujące. Wskazują w głąb Dasein. Lecz Da-sein jest zawsze-tak jak ja je rozumiem-moim (Dasein). Ponieważ one w tym wskazaniu, wprawdzie według swojej istoty, każdorazowo pokazują w konkretność poszczególnego Dasein w człowieku, lecz jej nigdy w swej zawartości nie przynoszą, toteż są one formalnie wskazujące ${ }^{48}$.

Heidegger stosuje także rozłączną pisownię Da-sein. W Sein und Zeit, pisane rozdzielnie $\mathrm{Da}$-sein, ma na celu zaakcentowanie ludzkiego bycia-tu-w-świecie. Po tak zwanym „zwrocie” (Kehre), zgodnie z Heideggera nowym konceptem myślenia bycia jako bycia samego, ta rozłączna pisownia nabiera innego sensu: podkreśla dystans ludzkiego bycia do jego „tu” w świecie, a także uwyraźnia bardziej sens „bycia” w człowieku. Czego dotyczy prze-

46 Tamże, s. 428.

${ }^{47}$ Pietyści zainicjowali w XVII wieku ruch religijny oparty na praktycznej pobożności. W XIX wieku ruch pietystyczny, zmierzający do ożywienia życia religijnego, wymierzony był przeciwko teologii spekulatywnej. Miał zwrócić uwagę na przeżycie religijne, którego źródłem jest studium Biblii. Aby słowo Boże właściwie rozumieć, rozwinęli pietyści swoistą hermeneutykę biblijną, w której wyróżniali: subtilitas intelligendi (rozumienie), subtilitas explicandi (wyjaśnienie) i subtilitas aplicandi (praktyczne zastosowanie).

${ }^{48}$ M. Heidegger, Die grundbegriffe der Metaphysik, Bd. 29/30, wyd. cyt., s. 429. 
miana dokonująca się w Da-sein? Przeznaczeniem formalnego wskazania jest doświadczenie sensu. Przemiana wiąże się z przyswojeniem sobie sensu. Przemiana dotyczy porzucenia starej i przyjęcia nowej postaci bycia. Przemiana jest przemianą w sensie. Dasein uwalnia się od mniej sensownego bycia ku bardziej sensownemu byciu. Być sensownie znaczy dla Heideggera być właściwą (eigentlich) egzystencją, a jednocześnie stawiać opór bezosobowej sile Man, rozpadaniu (Verfallen), zrujnowaniu (Ruinanz), które ciążą na dół, do bycia niewłaściwą (uneigentlich) egzystencją. Przemiana ta może również oznaczać jakościowy skok w Da-sein, w rozumieniu swojego bycia i bycia w ogóle. Wszystkie terminy filozoficzne mają ostatecznie egzystencjalny sens, to znaczy pochodzą z faktycznego życia i wracają do niego, aby je na nowo ożywić.

\section{Formalne wskazanie jako pojęcie operatywne}

Formalne wskazanie można zaliczyć do tak zwanych „pojęć operatywnych" (operative Begriffe). Nazwa "pojęcia operatywne” pochodzi od Eugena Finka, ucznia Husserla i Heideggera. Na konferencji poświęconej fenomenologii Husserla w kwietniu 1957 roku w Royaumont Fink wygłosił wykład „Operative Begriffe in Husserls Phänomenologie ${ }^{49 ”}$.

Komentując fenomenologię Husserla, Fink odkrył, że niektóre podstawowe pojęcia fenomenologii, takie, jak „fenomen”, „redukcja transcendentalna”, „konstytucja” pozostają „nieokreślone”. To nie znaczy, że Husserl je niedostatecznie wyjaśnił. Te pojęcia z natury posiadają „operatywne zacienienie" (operative Verschatung). Fink odróżnia pojęcia operatywne od pojęć tematycznych ${ }^{50}$. To, co operatywne, nie jest zasadniczo tematyzowane. Po-

${ }^{49} \mathrm{~W}$ niemieckim środowisku filozoficznym nie zwrócono specjalnie uwagi na Finka teorię pojęć operatywnych. Obecny na konferencji Jacques Derrida zachwycił się tą teorią i rozwinął ją w swojej teorii dekonstruktywizmu.

${ }^{50}$ „Rozróżniamy terminologicznie 'pojęcia tematyczne i operatywne’ [...] Myślenie utrzymuje się w żywiole pojęcia. Tworzenie pojęć we filozofii zmierza intencjonalnie ku takim pojęciom, w których myślenie utwierdza i przechwuje swoje pomyślane. Takie pojęcia nazywamy tematycznymi. [...] Lecz w tworzeniu pojęć tematycznych twórczy myśliciele używają innych pojęć i modeli myślowych, operują schematami intelektualnymi, których wcale nie doprowadzają do przedmiotowego utwierdzenia. Myślą oni poprzez określone przedstawienia myślowe w kierunku istotnych dla nich podstawowych pojęć tematycznych. Ich pojęciowe rozumienie porusza się w polu pojęciowych w medium pojęciowym, którego sami nie są w stanie objąć spojrzeniem. Wykorzystują medialne tory myślowe, aby ustawić to, co pomyślane ich myślenia. To, co tak omijająco wykorzystane, pomyślane, ale nie specjalnie przemyślane, nazywamy poję- 
jęcia operatywne mają charakter pomocniczy, naprowadzający, wskazujący. Poprzez pojęcia operatywne wchodzimy w relację z tym, co tematyczne. Przymiotniki „operatywny” i „tematyczny” nie są rozumiane jako właściwości pojęć, lecz oznaczają raczej sposób posługiwania się pojęciami. Jeśli na przykład myślimy czas, to myślimy czas w medium naszego rozumienia ruchu. Czas jest tutaj tematyczny, ruch operatywny. Fink twierdzi, że nie ma filozofii bez pojęć operatywnych. W każdej filozofii pewne pojęcia pozostają w cieniu. I te pojęcia muszą tam pozostać, ponieważ myślenie filozoficzne nie potrafi wszystkiego pomyśleć i wypowiedzieć. Nie potrafi ująć rzeczy bezpośrednio w pojęcia, bez pomocy innych pojęć pomocniczych. Posługiwanie się pojęciami operatywnymi i tematycznymi jest grą pojęciowego przenoszenia sensu. Pojęcia nie występują w sposób samodzielny i izolowany. Pojęcia operatywne nie muszą zawsze spełniać jedynie funkcji operatywnej. Zacienione, operatywne pojęcia mogą też być tematyzowane, to znaczy mogą wystąpić zarówno jako operatywne, jak i tematyczne. Wydaje się to sprzeczne, ale nie jest sprzecznością. Operatywne zacienione pojęcia mogą być w zasadzie tematyzowane, chociaż $\mathrm{w}$ określonych okolicznościach muszą one pozostać nietematyczne.

Formalne wskazanie może być rozumiane jako pojęcie operatywne, ponieważ występuje jako medium widzenia i rozumienia. Poprzez operatywność pojęcia formalnego wskazania mamy dostęp do pojęć filozofii egzystencji i myślenia bycia w ogóle. Formalne wskazanie może spełniać swoje zadanie zarówno jako pojęcie operatywne, jak i jako pojęcie tematyczne. Jako pojęcie operatywne występuje formalne wskazanie wtedy, kiedy na przykład wyjaśnia pojęcie „egzystencji”, pojęcie „dziejów”, pojęcie „początku”. Jako pojęcie tematyczne występuje formalne wskazanie wówczas, gdy samo jest wyjaśniane przez pojęcie „drogi”. Pojęcie formalnego wskazania może poruszać się w słońcu lub cieniu myślenia hermenutycznego Heideggera.

Formalnie wskazująca hermeneutyka przezwycięża systemowość filozofii. Fenomeny pokazują się i pozwalają się rozumiejąco zobaczyć w żywiole życia. Zasada metodyczna formalnego wskazania trzyma budowanie filozoficznych pojęć w otwartości i niezdecydowaniu. Pojęcia filozoficzne nie mogą stać się miejscami przechowywania stałego porządku. Formalne wskazanie kwestionuje tendencję do budowania filozoficznych pojęć, kierującą się intencją do wyznaczania ogólnego i ostatecznego porządku. Pozwala pozostać

ciami operatywnymi. Są one-mówiąc obrazowo-cieniem filozofii”. E. Fink, Nähe und Distanz. Phänomenologische Vorträge und Aufsätze, Freiburg /München 1976, s. 185-186. 
cały czas na drodze (auf dem Weg) i w drodze (unterwegs). Hans-Georg Gadamer pisze:

Powinniśmy wszyscy ciągle na nowo uczyć się, że Heidegger już w jego wczesnych pracach sformułował coś ważnego dla jego całego myślenia, kiedy mówi o 'formalnym wskazaniu'. Chodzi tutaj o coś decydującego dla całego przedsięwzięcia tego myślenia. Spuścizna fenomenologicznego pojęcia widzenia, względnie, oczywistości i ich wypełnienia, do czego fenomenologiczny sposób pracy jest $\mathrm{w}$ drodze, doświadcza tutaj zwrotu-w to, co egzystencjalne, jak i w to, co dziejowe ${ }^{51}$.

W hermeneutyce formalnego wskazania Heidegger usiłował odpowiedzieć na gruntowne pytanie, jak to, co jest skazane na skończoność bycia, może rozumiejąco wypatrzeć, zatrzymać, wyjaśnić, przemienić w sobie i wypowiedzieć to, co ze swojej istoty jest w ruchu i ukrywa się. Formalne wskazanie szuka punktu zaczepienia dla faktycznego i dziejowego życia, którego sensu nie daje się ustalić ani uprzedzająco (vorgreifend), ani retrospektywnie (rückgreifend). Dlatego pojęcia formalnie wskazujące pokazują jedynie Dasein w jego każdorazowej (Jeweiligkeit) i własnej (Jemeinigkeit) sytuacji.

\section{Bibiografia}

Heidegger M., Sein und Zeit, Unveränderter Text mit Randbemerkungen des Autors aus dem „Hüttenexemplar“, Hrsg. Fr.-W. von Herrmann, Gesamtausgabe, Bd. 2, Vittorio Klostermann, Frankfurt am Main 1977.

Heidegger M., Wegmarken, Text mit Randbemerkungen des Autors aus dem Handexemplar, Hrsg. Fr.-W. von Herrmann, Gesamtausgabe, Bd. 9, Vittorio Klostermann, Frankfurt am Main 2004.

Heidegger M., Logik. Die Frage nach der Wahrheit, Hrsg. W. Biemel, Gesamtausgabe, Bd. 21, Vittorio Klostermann, Frankfurt am Main 1995.

Heidegger M., Die Grundbegriffe der Metaphysik, Hrsg. Fr.-W. von Herrmann, Gesamtausgabe, Bd. 29/30, Vittorio Klostermann, Frankfurt am Main 2004.

Heidegger M., Zur Bestimmung der Philosophie, Hrsg. B. Heimbüchel, Gesamtausgabe, Bd. 56/57, Vittorio Klostermann, Frankfurt am Main 1999.

Heidegger M., Phänomenologie der Anschauung und des Ausdrucks, Hrsg. C. Strube, Gesamtausgabe, Bd. 59, Vittorio Klostermann, Frankfurt am Main 2007.

${ }^{51}$ H.-G. Gadamer, Neuere Philosophie I, Gesammelte Werke, Bd. 3, JCB Mohr, Tübingen 1999, s. 429. 
Heidegger M., Phänomenologie des religiösen Lebens, Hrsg. M. Jung, Th. Regehly, C. Strube, Gesamtausgabe, Bd 60, Vittorio Klostermann, Frankfurt am Main 2011.

Heidegger M., Phänomenologische Interpretationen zu Aristoteles. Einführung in die Phänomenologische Forschung, Hrsg. W. Bröcker u. K. Bröcker-Oltmanns, Gesamtausgabe, Bd. 61, Vittorio Klostermann, Frankfurt am Main 1994.

Heidegger M., Phänomenologische Interpretationen ausgewählter Abhandlungen des Aristoteles zur Ontologie und Logik. Anhang. Phänomenologische Interpretationen $z u$ Aristoteles (Anzeige der hermeneutischen Situation) Ausarbeitung für die Marburger und die Göttinger Philosophische Fakultät, Hrsg. G. Neumann, Gesamausgabe, Bd 62, Vittorio Klostermann, Frankfurt am Main 2005.

Heidegger M., Ontologie. Hermeneutik der Faktizität, Hrsg. K. Bröcker Oltmanns, Gesamtausgabe, Bd. 63, Vittorio Klostermann, Frankfurt am Main 1995.

\section{Abstract \\ Formal Indication as a Methodological Principle in Hermeneutical Thinking of Martin Heidegger}

Formal indication is one of the central concepts of Heidegger's hermeneutics. Formal means that something is to be fulfilled. Indication indicates the direction of fulfilling. Heidegger developed the so-called by him, "formal indication”, respectively "formally indicative concepts" as a methodological justification of the philosophical terminology. The term "formal indication” aroses in the context of the phenomenology of life, where Heidegger introduces his ",hermeneutics of facticity”, which is also referred to as "formally indicative hermeneutics". This is about something crucial for Heidegger's thinking. The epistemological and transcendental tradition of viewing finds here a turn into the existential and historical. The indication always remains at the distance of pointing, that is, someone to whom something is shown, must see for himself. Formal indication indicates the direction for seeing. What can be seen, one must learn to say, to say in the own words. The old problem of the concretization and the conceptualization, which runs through German idealism, gets here a new expression.

Key words: Heidegger, formal indication, hermeneutic, methody 